\title{
RE-ENGINEERING THE LOCAL STATE: PARTICIPATION, SOCIAL JUSTICE AND INTERLOCKING INSTITUTIONS
}

\author{
Redesenhando o governo local: participação, justiça social e articulação interinstitucional
}

\begin{abstract}
The municipalization of basic social service delivery in Brazil provides significant incentives for local public officials to have a better understanding of their constituents' needs and requirements both to govern and for political purposes. The broadening of participatory venues under the 1988 Constitution allowed for the establishment of a broad number of public venues that civil society leaders could use to represent their associations. Government officials and civil society leaders have constant contact with each other as each seek to promote polices that advance their narrow and broader concerns. This article focuses on the establishment of three governing principles of five successive governments in Belo Horizonte: Social justice, popular participation, and interlocking institutions. The government and its allies in civil society redesigned citizen access points into the state as means to clarifying the signals sent from citizens to government officials, to allow civil society organization (CSO) leaders to act as intermediaries between citizens and public officials and to allow government officials' to tap into CSO leaders and citizens' attitudes on a wide range of pressing political issues. These interlocking venues are a key moment of interest mediation, which partially accounts for how Belo Horizonte produces robust social policy change in a context of a highly fragmented party system. Participatory governance is now the key mechanism that allows for constant dialogue among citizens and government officials. This article is part of a larger research project seeking to understand how and why the local Brazilian state was restructured in the 1990s, how citizens are incorporated into state-sanctioned governance bodies, and importantly, how the new institutional environment has helped to transform state-society relations.
\end{abstract}

Keywords: Participation; state reform; civil society; local public officials; municipalization.

Brian Wampler bwampler@boisestate.edu

Ph.D. University of Texas, Austin

Boise State University, United States

Em conformidade com o Manual de Boas Práticas da Anpad, este artigo foi submetido aos mesmos critérios de avaliação adotados para todos os textos dos Cadernos Gestão Pública e Cidadania, tendo sido aprovado após exame pelo critério double blind peer review.

Artigo submetido no dia 30.05.2012 e aprovado em 28.11.2012

\section{Resumo}

A municipalização do atendimento social básico no Brasil cria incentivos significativos para que os servidores públicos locais entendam melhor as necessidades e demandas de seus eleitores para governar e para propósitos políticos. A expansão de espaços de participação amparada pela Constituição de 1988 permitiu que se estabelecesse um número amplo de espacos em que as liderancas da sociedade civil poderiam representar os interesses de suas associações. Funcionários governamentais e líderếs da sociedade civil tệm contato constante uns com os outros, uma vez que cada um busca promover políticas que ampliem seus objetivos amplos e específicos. Este artigo tem como foco o estabelecimento de três princípios de cinco governos sucessivos em Belo Horizonte: justiça social, participação popular e articulacão interinstitucional.

0 governo e seus aliados da sociedade civil redesenharam os pontos de acesso ao Estado como forma de clarificar os sinais enviados pelos cidadãos às autoridades governamentais, para permitir que os líderes da sociedade civil organizada atuem como intermediários entre os cidadãos e as autoridades pubblicas e que as autoridades governamentais estabeleçam uma forte aliança com as lideranças da sociedade civil e com os cidadãos em relacão a um amplo espectro de temas que são objeto de pressões políticaś. Esses canais de articulação são momentos-chave de mediação de interesses, que parcialmente explicam como Belo Horizonte produz uma robusta mudança na política social num contexto de sistema partidário altamente fragmentado. A governança participativa é agora o mecanismo chave que permite um 
diálogo constante entre cidadãos e autoridades governamentais.

Este artigo é parte de um grande projeto que procura entender como e porque o governo local brasileiro foi reestruturado nos anos 1990, como os cidadãos são incorporados e sancionados pelos corpos governamentais, e de modo importante, como 0 novo ambiente institucional tem ajudado a transformar as relações Estado-sociedade.

Palavras-chave: Participação; reforma do Estado; sociedade civil, política local; municipalização.

\section{Introduction: Expanding the State's Surface Area}

Brazilian municipalities are now the sites of extensive policy innovations and institutional reengineering as government officials and their civil society allies have used authority extended by the 1988 Constitution to reconfigure how citizens will be incorporated into policymaking processes. Civil society leaders and citizens now have multiple access points to Brazilian municipalities, which has led to the demonopolization of the political control that was traditionally exercised by mayoral administrations. In some Brazilian municipalities, we now see civil society organizations (CSOs) and local government officials coordinating their policymaking activities as they seek to use municipal resources and authority to transform the lives of ordinary citizens. This article examines key institutional innovations that illustrate the complexity of the modern municipal state in Brazil. The implementation of significant policy changes was predicated on the ability to reform the administrative structure of the state, improve internal decision-making processes, and encourage new forms of citizen engagement.

This article explores the political processes and institutional venues through which citizens and government officials can connect with each other through a participatory governance architecture. The article addresses the following question:
How has an expansive participatory governance architecture altered the local state? This article shows how the current institutional environment embeds citizens and community leaders in the local state, while also incorporating government officials into civil society organizations. There is now a blurring of the line between state and society. The redesigning of the local state is an attempt to address the interrelated problems of an inefficient social service system and the limited participation of citizens in representative democracy. Citizens and government officials are engaging in public venues in unprecedented ways, which is altering basic state-society relations.

This article devolves the empirical lens to Belo Horizonte to demonstrate how the local state was reengineered to allow five successive municipal administrations to turn their rather amorphous campaign pledges (involving an "inversion of priorities") into specific benefits for the population. These gains are material as greater levels of resources are spent on low-income communities, but also sociocultural and political, as witnessed by the notable changes in political participation, public deliberation and representation. A greater number of citizens are now able to exercise their constitutionally-mandated social and political rights. By narrowing our focus to the local state, it becomes possible to understand how state authority can be harnessed to produce social change.

Belo Horizonte is an exceptional city 
and has long been at the fore of municipal level changes. It was Brazil's first planned city in the 1890s and the Pampulha region was created in the 1950s. As I argue in this article, Belo Horizonte was the site of a significant experimentation that led to the establishment of a participatory municipal state. Although Belo Horizonte is exceptional, the process of change in Belo Horizonte provides important clues as to the future of municipal reform in Brazil. The types of institutional changes identified in this article are occurring throughout across Brazil, as municipalities adopt councils (conselhos), hold policy conferences and set up other participatory institutions. The broadening of the state will transform how citizens and public officials interact at all levels of government across Brazil. The pace and extent of change will obviously not unfold the same way as it has in Belo Horizonte, but the institutional changes will produce similar incentives for citizens to engage public officials in similar ways. Therefore, Belo Horizonte's experience of the past two decades is a forerunner to the shape that other municipalities, state, and the federal government is now taking. The Brazilian state is being broadened, allowing new interests and issues to be addressed. By focusing on the exceptional, innovative city of Belo Horizonte, we can identify key processes and impacts that are unfolding across Brazil.

Participatory governance institutions produce new forms of interest mediation among state and society actors, filling a political need created by weak parties, an insulated and often unresponsive bureaucracy, and low levels of knowledge, information, and power held by ordinary citizens. Today, many government officials use the new institutional structures to reach out to the organized public, especially groups and individuals living in favelas to gain a clearer sense of citizens' needs and demands. Participatory governance institutions have been grafted onto existing state institutions and representative democracy; they now serve as ligatures that connect citizens and CSO leaders to formal state institutions. It is the infusion of new ideas, new actors, and new programs into participatory governance venues that is regenerating democratic practices. This does not mean, of course, that traditional local level practices, such as clientelism and cooptation, have disappeared. They continue to exist at the local level. At times, clientelism occurs parallel to the new participatory institutions while at other times, clientelistic exchanges are embedded in the informal negotiations that surround these institutions. And yet, individuals who are potential clients of clientelistic brokers now have a greater set of opportunities to move beyond clientelistic exchanges. The broadening of the local state has greatly expanded how citizens can access the state.

The local state is now at the fore of democratic innovation and political change due to several interrelated processes. First, the renewal of civil society and party politics during the 1970s and 1980s altered basic forms of social and political organizing. The rise of social movements, the expansion of community organizations, the development of independent labor unions, and the growth of the Workers' Party altered the range and numbers of citizens involved in political struggle (KECK, 1992; ALVAREZ, 1990; DAGNINO, 1994; AVRITZER, 2002; 2009; HOLSTON, 2009). The organization of actors generated a critical juncture as it produced new institutional arrangements and forms of state-society interactions (COLLIER; COLLIER, 1991; KEY, 1964). This critical 
juncture is quite different from the labor-driven critical junctures described in considerable detail by Collier and Collier, since the main protagonists were civil society actors, labor unions, and opposition political parties seeking to expand access to rights and the terrain of representative democracy.

The second part of this process is the promulgation of the 1988 Constitution, which is a useful marker to imagine the formal institutionalization of the critical juncture. The 1988 Constitution formally established new social new rights, led to the devolution of authority and resources to municipalities and states, and permitted governments to experiment with new types of institutions. . The 1988 Constitution is a sprawling document, that contains a wide range of rights and institutional arrangements, many of which were included as a result of the organizational efforts of an energized civil society. The 1988 Constitution provided an opportunity to link an organized and mobilized civil society with newly empowered municipal governments. Thus, the 1988 Constitution marked a new period in which civil society activists and elected officials would be able to experiment with new policies and programs that, they hoped, would improve democratic practices and enhance people's social well-being.

\section{What is participatory governance?}

Participatory governance consists of state-sanctioned institutional processes that devolve decision-making authority to venues jointly controlled by citizens and government officials. Central to this definition is that these processes are jointly controlled, suggesting that we must consider the strategies and behaviors of citizens and government officials. Citizens exercise voice and vote.
They directly engage with each other and government officials in ongoing meetings and public forums. They listen, deliberate and negotiate with each other and government officials. Citizens typically vote for different policy options, specific projects and internal citizen-representatives. Government officials administer and implement. They administer the participatory governance programs, providing the necessary logistical support to ensure that the meetings function well. Government officials receive the policy decisions (binding or recommendations) made by citizens and then mobilize the bureaucracy to implement these policies.

In Brazil, there are now three principal institutionalized forms of participatory governance-public policy management councils (conselhos), thematic policy conferences (confêrencias) and participatory budgeting (orçamento particpativo). Although these are part of a similar institutional "family," there are significant differences regarding who participates, who is represented and how public deliberation occurs.

In this article, I narrow the theoretical and analytical lens to show the municipality of Belo Horizonte transformed how state-society relations by re-building the state. This article begins with a brief review of the importance of state formation before turning to the case study.

\section{State Formation}

"The state continually morphs." (MIGDAL, 2001: 23).

The capacity of local states is integral to how participatory governance institutions are founded, how they function as well as their potential impact on enhancing the quality of democracy and improving social well-being. 
Atul Kohli's work on state formation and late industrialization is a useful start point because it shows how variation in state formation had a significant impact on the ability of countries to industrialize. "The creation of effective states within the developing world has generally preceded the emergence of industrializing economics (KOHLI, 2004: 2). In a parallel fashion, we find that the creation of effective local states is strongly associated participatory governance's impact. State officials are intimately involved in how participatory governance functions, which means that state capacity and effectiveness is an integral part of the potential impact of this process.

"The key theoretical problems of understanding state intervention in developing country economies are thus to identify how effective state power for development is generated and how this power is used to promote economic change." (KOHLI, 2004: 418)

Kohli's work on economic development is applicable to understanding the role of the state in fostering democracy. In the quotation below, I have replaced key words from Kohli's original statement with words related to political development.

The key theoretical problems of understanding state intervention in developing country democracies are thus to identify how effective state power for the expansion of citizenship rights is generated and how this power is used to promote political and social change. (Adapted from Kohli)

The type of state formation is integral component to participatory governance because these new institutions incorporate citizen voice into a policymaking processes that result in state action. When states are unable to implement citizens' policy choices, it undercuts citizens' voice, which has a corresponding negative effect on the development of a new state. Thus, effective states are more likely to advance the democratizing project associated with participatory governance because they are able to mobilize the state to enact change (ABERS; KECK, 2007). But what is crucial is how states develop the institutional access points to develop and implement policies.

James C. Scott, in Seeing Like a State, demonstrates how states utilize simplification projects, whereby the state seeks to transform the unmanageable and illegible into the manageable and legible, which then allows the state to act upon and control previously unruly individuals, communities, and "wild" spaces.

State simplifications such as maps, censuses, cadastral lists, and standard units of measurement represent techniques for grasping a large and complex reality; in order for officials to be able to comprehend aspects of the ensemble, that complex reality must be reduced to schematic categories" (SCOTT, 1998:77).

Scott's work demonstrates that many of these transformative projects had disastrous consequences for nature, cities, communities, and individuals due to the authoritarian practices employed by states.

Scott's argument addresses the problems created by the state acting on society, but he does offer a way outcombining expert knowledge with practical, 
local knowledge. "Broadly understood, metis represents a wide array of practical skills and acquired intelligence in responding to a constantly changing natural and human environment" (SCOTT, 1998: 313). Although Brazilian civil society activists and government officials designing new participatory institutions may not have been familiar with the Greek concept of Metis, the participatory governance system they devised captures the spirit of this concept-linking expert and elite knowledge with ideas, information, and knowledge of ordinary citizens. Government officials use scientific knowledge to ground the debate (civil engineering, budget rules) and to broaden the debate (e.g., the use povertybased indicators to distribute wealth) and they also draw upon the practical knowledge from citizens and CSO leaders to guide the process of project selection and urbanization.

Citizens and CSO leaders living in crowded favelas seek out state support because they desperately want access to the expert knowledge that might "simplify" their neighborhoods and produce better living conditions. These community leaders wanted access to state authority and resources (public or private) that generated a high quality of physical infrastructure in middle and upper class neighborhoods. Although Scott worried about the dangers of a "simplification" process, these plans can empower citizens, community groups, and social movements in urban favelas as they struggle to obtain the same types of pubic resources enjoyed by middle class and elite neighborhoods. The municipal government in Belo Horizonte, in conjunction with policy experts (often university faculty) and civil society organizations, used information collected by the federal government's census bureau to justify the transfer of resources to low-income neighborhoods. The institutional changes that allowed for new forms of local state formation were consolidated at the national level in the 1988 Constitution.

\section{Critical Juncture: 1988 Constitution}

The 1988 Constitution enacted three significant changes pertinent to this article's argument: Municipalization of authority and resources, expansion of participatory venues, and formal legal codification of social rights. Following the promulgation of the 1988 Constitution, the Brazilian state was restructured so that different levels of state and a mixture of government could begin the process of addressing the massive social, economic and political exclusion faced by the majority of citizens. It should be remembered that Brazil is one of the most unequal countries in the world-parts of São Paulo appear to be like Manhattan but other Brazilians live in conditions more similar to the poorer parts of Central America. Following the 1988 Constitution, local states were rebuilt with considerable variations. Some municipalities chose to rebuild on the basis of an elite decision-making model (Curitiba), others a clientelistic model (Rio), and others a participatory model (Belo Horizonte, Porto Alegre).

\section{Municipalitization}

The new federal arrangement was decentralized and 'municipalized', with states and municipal government having greater control over financial resources and the provision of social services. Municipalities follow federal and state guidelines to ensure the ever-important transfer of resources, but they also have considerable flexibility to 
develop their own projects, their own agendas. They are now responsible for a wide range of social policies, including the public health care system (SUS - Sistema Único de Saúde), education (often shared responsibility with state government), housing, infrastructure, some local policing, and social services. Municipal governments control $15 \%$ of all public expenditures (MONTERO; SAMUELS, 2004).

Municipalities are responsible for providing public services that would help citizens access to their constitutionallyguaranteed social rights. The 1988 Constitution formally guaranteed Brazilians a wide range of social rights but it is the lower tiers of the federal system that are now responsible for ensuring that individuals' constitutional rights are protected. This illuminates the importance of this article's focus on the municipal level. Citizen's municipal government strongly influences the types of services they receive, which in turns affects which types of social rights they are able to develop.

Although the 1988 Constitution devolved significant authority to municipal governments, there was a recentralization process during the late 1990s and throughout the 2000s. "Lei Kandir", the law of fiscal responsibility, set specific limits on how municipal governments must spend resources transferred from the federal government. Most municipalities depend on direct transfers from the federal government. Wealthier municipalities, often in the south and southeast part of the country, have access to property taxes and sales tax, but this is a smaller fraction of their resources. The Lei Kandir requires that municipal governments spend at least $30 \%$ of the total budget in the area of education and $25 \%$ in the area of health care.
In sum, municipalities are important actors in the new federal compact; they spend nearly $15 \%$ of all public funds on public policies such as health care, housing, social services, etc. The federal government provides general guidelines for how municipalities may spend resources, but there is considerable discretion for how mayors and governors can design and implement programs.

\section{Participatory Venues}

Under the 1988 Constitution, the direct participation of citizens in policymaking processes is now explicitly permitted. In Elinor Ostrom's Nobel prize winning work, she employs the concepts of requires, permits, and forbids to illuminate the different types of authority that might be extended to the local level by national or federal governments (OSTROM, 1990: 91). The 1988 Constitution now permits federal, state, and municipal governments to include direct participation of citizens in policymaking processes, thereby providing greater flexibility to allow government officials to innovate (OSTROM 1990). State and municipal governments then can choose to hold public meetings, to reach out to different constituencies without having to draft legislation or write new program rules.

Federal legislation takes an additional step and requires that state and municipal governments adopt specific types of participatory venues. In public policy arenas of vital important (i.e. education, health care, social services), public policy management councils are now required at federal, state, and municipal levels. This ensures a vertical integration of the public policy arena and it also ensures that citizens and CSO leaders will be able to participate in the policymaking process at three distinct levels. In sum, the 1988 
Constitution marks a shift in how the Brazilian state would allow citizens to be engaged in public venues. It was not clear during the 1986-1987 Constitutional Assembly that Brazilian subnational governments would emerge as the laboratories of democratic innovation. The 1988 Constitution created an opportunity allowed for a reorganization to local states; the evidence now shows that new coalitions of civil society actors and political reformers were able to alter how local states function.

\section{Social rights}

Finally, the 1988 Constitution also expanded the number of collective social rights (e.g. right to education, housing, health care, etc), which are aspirational because the cost for the state to provide the rights is astronomical. Although the Brazilian government has been unable to meet constitutional guarantees that all Brazilians have access to health care, housing, education, a decent retirement, etc, the inclusion of these rights in the Constitution is understood by many political activists to be a significant advance because it crafted a clear institutional framework that citizens could use to pressure governments to act.

Because these rights are also legally guaranteed the state finds itself subject to an ongoing number of lawsuits because people are unable to access their rights. Thus, the quality and breadth of social programs produced by local governments can have a significant impact on the extent to which collective rights can be utilized by individuals. There is now a tension in Brazil's federal system whereby municipal governments are responsible for the provision of public policies such as housing and health care but lack the resources, infrastructure, and technical competencies to carry it out. A classic problem of unfunded mandates. However, the devolution of authority has produced the opportunity for innovations and new ways of developing and implementing public policies.

The opportunity to unleash new programs and institutions has occurred most significantly at the municipal level. Mayoral administrations used the authority afforded to them under the 1988 Constitution to devise new ways to address chronic social and political problems. The next section sets up the analytical framework to evaluate how the state and society have been reconstituted.

\section{The 1990s: charting a new course in Belo Horizonte}

The 1992 election of Patrus Ananias (PT) launched a transformative project. The electoral realignment in Belo Horizonte was driven by the same forces that led to institutional changes in the 1988 Constitution that were discussed above: The mobilization of leftist social movements and labor unions, the extensive engagement of a Catholic Church hierarchy associated with Liberation Theology, and an engaged university community (faculty \& students) as well as community-based organizations seeking to improve their communities.

The two main parties of the political coalition, the Workers' Party and the Brazilian Socialist Party, were elected to the mayor's office four additional times (1996, 2000, 2004, 2008). Over the past twenty years, Belo Horizonte's municipal government has been at the forefront of innovative reform efforts in Brazil, leading to a redesign of the local based on three pillars: The expansion of social justice, the inclusion of citizens 
directly into participatory venues, and the establishment of interlocking institutions. The electoral victory of Mayor Patrus Ananias in 1992 marks a significant shift in how the local government's policy priorities as the PT administration focused on social justice, participatory governance, and interlocking institutions. The electoral victory of Patrus Ananias was unexpected because he was a member of the Workers' Party, which was still attempting to carve out space in local and national elections. In 1989, the Workers' Party won important mayoral races in São Paulo, Santo Andre and Porto Alegre, but the party was only the fourth or fifth most important party at the municipal level in 1992.

Patrus Ananias was a two-term municipal legislator and university professor when he ran for the mayor's office in 1992. During the 1989-1992 term, he served as the President of the Municipal legislative, and worked to draft and pass a new city Master plan. Patrus worked extensively with housing social movements, community-based organizations, urban planners, university faculty, and the business community, to design the new city Master plan. Finally, Patrus Ananias had longstanding and deep ties to the progressive wing of the Catholic Church. He worked within the Liberation Theology sector of the Catholic Church that was quite influential, socially and politically, in the state of Minas Gerais. The Workers' Party political project in Belo Horizonte is captured by Navarro:

Their campaign document, 'A Democratic and Popular Agenda,' was the basis for the political coalition. The point of departure is the implementation of the municipality's new charter and there are several references to the establishment of a "democratizing project" in the administration of the city and its urban policies." (NAVARRO, N.D.)

The Vice Mayor, Célio de Castro, was from the Socialist Party of Brazil (PSB), a center-left political party but he also longstanding ties to the Communist Party of Brazil (PC do B), which had a much more radical political agenda. Thus, the governing coalition led by Mayor Patrus Ananias and Vice-Mayor Célio de Castro was comprised of political leaders outside of the traditional elite that dominated Minas politics. The transformative project was built on the pillars of social justice, popular participation, and interlocking institutions. The 1988 Constitution, and its sprawling design, also promotes these three pillars. Thus, a key lesson of the Belo Horizonte case is that as the 1988 Constitution becomes an actively enforced document that more and more Brazilians will live under political rules resembling Belo Horizonte. Public policy management councils, participatory budgeting, and the federally promoted conference system are share these three pillars of change; these institutions are being employed across Brazil.

\section{Social Justice}

In order to promote social justice, the Patrus government needed to rethink which social services and public policies would to provide to which groups. The concept of social justice is a rather amorphous concept so the principal challenge for the government was to develop innovative rules, policies, programs and institutions to allow public resources and state authority to be harnessed in the pursuit of improving the lives of poor citizens. These innovations are part of a broader "post-liberal" challenge, as described by Debora Yashar, whereby there are demands for individual 
rights intrinsic to liberal representative democracy as well as group-based rights that recognize the significant structural and economic differences of citizens (YASHAR, 2005). Elinor Ostrom's work on common pool resources is applicable here as "rules of the games" within the participatory institutions allocate state authority and resources and set the tone for who will be represented within the new institution (1990).

To achieve a post-liberal form of statesponsored social justice, the government in Belo Horizonte created new "Techniques of Access," which consist of the broader set of rules, programs, and policies that make the amorphous qualities associated with social justice into specific, concrete improvements in social well-being. From the "right to food" to a reduction in malnutrition. From the "right to voice" to infrastructure projects in shantytowns. "Techniques of Access" links a broad goal of promoting social justice with the authority secured when a government gains control of the local state. The following set of institutional design principles of social justice-oriented participatory programs were influenced by the work of Ostrom, and Fung and Wright (OSTROM, 1990; FUNG; WRIGHT, 2001; 2003). The design principles obviously share much in common with Fung and Wright but the principal difference is that social justice concerns are addressed at each stage of the process.

\section{Table 1: Participatory Governance Design Principles}

\begin{tabular}{|c|c|}
\hline $\begin{array}{l}\text { Decentralize } \\
\text { city-level } \\
\text { government }\end{array}$ & $\begin{array}{l}\text { - } \text { Allows targeted populations to make decisions on local issues } \\
\text { - Links bureaucrats and policy experts at neighborhood level } \\
\text { - Distributes resources on a per capita basis with poorer } \\
\text { neighborhoods receiving greater levels of funding. }\end{array}$ \\
\hline $\begin{array}{l}\text { Reward } \\
\text { mobilization }\end{array}$ & $\begin{array}{l}\text { - Permits citizens to directly vote on policy outcomes } \\
\text { - Draw attention to policy issues that have strong relevance to targeted } \\
\text { communities (e.g. basic infrastructure; health care clinics) } \\
\text { - Allocates resources based on need and population-poorer } \\
\text { communities receive greater levels of public resources }\end{array}$ \\
\hline $\begin{array}{l}\text { Expand } \\
\text { Deliberative } \\
\text { venues }\end{array}$ & $\begin{array}{l}\text { - Encourages citizens to debate each other and government officials } \\
\text { - Provides information to citizens to allow them to hold a more } \\
\text { substantive debate on government priorities and state responsibilities } \\
\text { - Permits citizens to question the (in)actions of government officials } \\
\text { and community leaders }\end{array}$ \\
\hline $\begin{array}{l}\text { Promote new } \\
\text { networks and } \\
\text { alliances }\end{array}$ & $\begin{array}{l}\text { - Links citizens to government officials; citizens to other citizens; } \\
\text { CSOs to CSOs } \\
\text { - Fosters growth alliances among poor } \\
\text { - Establishes new intermediaries in the absence of strong parties. }\end{array}$ \\
\hline $\begin{array}{l}\text { Engage in } \\
\text { oversight }\end{array}$ & $\begin{array}{l}\text { - Allows citizens and CSOs to monitor policy implementation } \\
\text { - Helps citizens to gather information about ongoing policy efforts } \\
\text { - Promotes more efficient and effective use of state funds }\end{array}$ \\
\hline
\end{tabular}




\section{What are some of the specific examples?}

Technique of Access \#1: Index of the Quality of Urban Life

The Workers' Party government in Belo Horizonte a Quality of Urban Life Index (Índice de Qualidade de Vida Urbana-IQVU) as a means to provide a clear rational for how resources would be allocated to low-income neighborhoods within participatory budgeting. Communities with a lower quality of life would receive a greater per capita share of resources. The IQVU provides the technical rational that allows the government to legitimize (politically, morally) the allocation of resources to lowincome communities. The IQVU represents a fusion of the Workers' Party's political project (social justice) with technical, expert knowledge made available through a fairly capable state and high quality university system. The index is part of explicit attempt to reimage how state authority can be used.

The technical logic behind the IQVU is to establish a clear map of public and private infrastructure in 81 planning units (roughly 9 per region). It was originally devised to guide the discussion on the 1995 Master Plan but later became an integral part of the Participatory Budgeting Process.

It is comprised of 75 separate components that seek to measure local service delivery and public infrastructure in the following areas: Food security, social services, culture, education, sports, housing, infrastructure, health care, public security, and urban services. Based on these objective criteria, the IQVU allows us to identify those planning units were there is a lower access to services. Those planning units should receive priority in the distribution of available resources as well as those government departments that need to expand services to increase the
IQVU in the planning unit." (NAHAS, n.d.:7).

The 75 components did not require new data collection, but required that the government use the data in ways that would help them achieve their goal of social justice. Importantly, the criteria for what should be included in the IQVU as well as the weight of different indicators was done in conjunction with the "street level" bureaucrats who had an intimate understanding of the diversity of problems within each favela as well as across favelas (Nahas, 2000; Nahas n.d.:14; Lipsky 1980). These street level bureaucrats had the local and practical knowledge but they had no systemic means to measure these differences. The IQVU allows their knowledge to be accumulated in a much more systematic way, which gave the government a much better understanding of the problems faced by favela residents.

This is an excellent example of how state interest and local knowledge can be combined to produce successful policy outcomes, thus overcoming James Scott's warning about how simplification projects often lead to negative outcomes. The first type of local knowledge was that of the street level bureaucrats, but the second step would be to incorporate citizens' knowledge into the process. The IQVU, originally developed for the 1995 Master Plan, becomes part of an official component of participatory budgeting process in 1996. Thus, the IQVU is then linked to participatory governance institutions to allow citizens to decide on how they will spend the resources allocated to their region or micro-region. In sum, the role of this tool is to link demands and needs to the technical and professional expertise of the local state. Elected officials and their appointees signal the directions in which the state can be crafted. 
Techniques of Access \#2: Food Security In the area of food security, Mayor Patrus established a moral and political right to a nutritious and healthy diet (MACHADO et al, 2009). Again, this is an amorphous right; it is quite difficult to create the policies and programs to get decent foods into poor households and public schools. To achieve this goal, Patrus reorganized the local state. Successful programs include the creation in the of the number and location of municipal-run popular restaurants (in 2010, breakfast was 35 US cents and lunch was 70 US cents), the creation a farm-tomarket program delivering food to schools and to public markets located near favelas, the 1993 establishment of the Secretaria Municipal de Abastecimento (SMAB) and the 1994 food security public policy management council (MACHADO et al, 2009). By 2009, the municipality of Belo Horizonte, had 29 different social programs that focused on food security and nutritional issues (MACHADO et al, 2009: 96-98). Thus, we can assert that the strong emphasis on food security by Mayor Patrus led to the institutionalization of social programs that successfully improved access by low-income families to inexpensive food.

The purpose of the public policy management council was to bring public experts, elected officials, CSO leaders into a single body to devise the strategies that would enable them to address policy outcomes in a coherent manner. By bringing a diversity of voices to a single institutional channel, the government developed better programs and, importantly, they create a common language among "public opinion makers" in this area. Each social justice component is then linked to the second pillar: participatory governance institutions.

However, there are real limitations to how social justice can be achieved through the new state. First, trying to achieve social justice at the local level is limited by the relatively low levels of resources held by municipalities. Municipal governments spend roughly $15 \%$ of all public resources, but the majority of this is allocated to personnel and salaries, which means that there is a limited supply of resources to promote social change. The Brazilian federal government, through a program like Bolsa Família has a greater ability to influence social justice due to greater resources and number of potential beneficiaries. A second limitation is that it appears that much of PB's implementation success is related to expanding what the state does rather than creating new policy outputs. Simply put, moderate state capacity in cities like Belo Horizonte or Porto Alegre in the 1990s was harnessed by municipal governments to implement public works in areas that had been underserviced. These governments weren't creating new state capacity but they were using existing state authority and capabilities in new location. Thus, smaller municipalities often don't have the basic state capacity to achieve some of the basic social justice principles embedded in the 1988 Constitution.

\section{Popular participation}

The second pillar of the new governing coalition in Belo Horizonte was the strong support for the direct incorporation of citizens into policymaking venues via participatory governance. Beginning under Mayor Patrus Ananias (1989-1992), the government established new venues that would allow citizens to obtain information, to access government officials, and to directly intervene in the policymaking process. As one housing movement leader told me in an interview, 'We organized before Patrus' government, but Patrus was important because he 
opened doors..., He worked to ensure the inversion of priorities." In the area of popular participation, Mayor Patrus carried out a series of reforms, including adoption of Participatory Budgeting in 1994, PB Housing in 1996 and the creation of nine public policy management councils (AZEVEDO; FERNANDES, 2005; AZEVEDO; NABUCO, 2008; AVRITZER, 2002; WAMPLER, 2007: MACHADO, 2007:88-89).

There are two basic types of authority that characterize participatory governance institutions-co-governance (co-gestão) and accountability (controle social), although there is significant variation among the councils, participatory budgeting and the conferences. Co-governance includes the right to be directly involved in policymaking process, which includes gaining access to information, working on technical subcommittees, deliberating in public sessions, and engaging with their fellow council members. Citizens' voice is part of the policymaking process. A second key responsibility granted to participants is the right to monitor the use of public resources and the implementation of public works and social services. The rules guiding these institutions are premised on the idea that the expansion of the number of people monitoring how bureaucrats and private contractors allocate and spend public resources, will result in lower levels of corruption.

By 2010, there were 571 different public policy management councils (conselhos) with more than 4,000 "seats" that citizens could hold. The municipal state is now open for direct and consistent negotiations with citizens at municipal, regional, and local levels. This is remarkable in the context of Brazil's long history of social and political exclusion. Councils at located at municipal, regional (nine), and local level. The expansion of the number of participatory seats indicates that the local government has consolidated a broad participatory infrastructure.

Table 2 - Public Policy management councils: Venues and Formal representation for Citizens, Government Officials, and Unions in 2009-2010

\begin{tabular}{|l|l|l|l|l|}
\hline \# of & Municipal & Regional (9) $^{\text {i }}$ & Local $^{\text {ii }}$ & Total \\
\hline Participatory Governance Venues & 41 & 52 & 479 & 571 \\
\hline Seats for: & & & & \\
\hline Government officials & 325 & 124 & 1406 & 1855 \\
\hline & & & & \\
\hline Citizens/CSOs & 309 & 377 & 2725 & 3411 \\
\hline Union Officials & 35 & 132 & 141 & 308 \\
\hline Service Providers & 64 & N/A & N/A & 64 \\
\hline Total & 733 & 633 & 4272 & \\
\hline
\end{tabular}

Sources: Data drawn from Martins Machado 2007 and based on original research 
At the regional level, there are different types of participatory venues-planning units, hospitals, social service centers, day care centers, etc. These bring together a broader cross-section of residents than the participatory venues at the local level. Table 2 also shows that most of the "seats" for citizens are at the local level in the education and health care sectors. Low-income and lower- middle class citizens rely on publicly funded education and health care, so these citizens have a higher interest in the local and regional councils because they depend on the state for these public goods. These include parents who are involved in their children's schools and individuals who rely on the public health care systemparents of young children, the elderly and their caregivers, and the chronically ill. We should note that middle and upper- class individuals and families tend not to rely on the public provision of health care or education because they have the financial means to pay for privately- funded, market-oriented services. This means that the middle-class will have an incentive to be involved in the public policy management council system. The government drew from the successful case of Porto Alegre's PB to initiate participatory budgeting. The basic principles were adopted from now famous case in Porto Alegre, but the program was adapted to meet local needs and demands (ABERS, 2001; BAIOCCHI, 2005; FEDOZZI, 1998; 2000. For an important discussion of local innovation and adaption, see BAIOCCHI; HELLER; SILVA, 2011). Most importantly, the government developed the Quality of Life Index (IQVU), which became the basis for the distribution of resources. As shown below, in Table 3, participatory budgeting now has three separate components: regional, housing and digital, each with different means and ends. What links the three PB programs together is an effort to keep a direct link between citizens' active participation in a state-sanctioned institutions and the distribution of public resources.

Table 3 - Participatory Budgeting and Conferences 2008-2009

\begin{tabular}{|l|l|l|l|}
\hline \# of & Institutional venues & $\begin{array}{l}\text { Numbers of } \\
\text { Participants } \\
2008 / 9^{\text {iii }}\end{array}$ & PB Delegates \\
\hline PB Regional & 9 regions & 40,967 & $1200^{\text {iv }}$ \\
\hline PB Housing & 6 regions & 13,000 & 599 \\
\hline PB Digital & Online & 113,383 & N/A \\
\hline & & & \\
\hline Policy Conferences & 19 & $9,000^{v}$ & N/A \\
\hline
\end{tabular}


The one point I want to emphasize is the government consistently sought to reform the process to better align it to correspond to citizens' demands and government capabilities. For example, when it became obvious in 1994 and 1995 that demands from the housing movements might overwhelm the participatory budgeting process, the government established "PB Housing" in 1996 to incorporates the housing movement's demands. The housing social movements were on the verge of overwhelming the main participatory institutions due to their high levels of mobilization. The housing public policy field is further complicated because the public good under discussion (apartment units) will be allocated to individuals for their private use. In 2006, the government established "PB Digital" to reach out to middle class and youth sectors who were not participating in the more traditional PB processes.

The final institutional component are the policy conferences (see Table 3 above), which incorporate citizens and community leaders into day or weekend-long workshops that focus on specific policy arenas (e.g., health care, housing, education). The purpose of these conferences is to allow citizens to share ideas and connect with each other and, to enable them to demonstrate their policy preferences to government officials. They are also designed to permit ordinary citizens to show their solidarity with their leaders and movements as well as to lay down general policy recommendations. Policy conferences do not make binding decisions but form a part of a consultative process in which the exchange of information is crucial. These are held at a municipal level, but are often linked to state and federal policies.

Theinstitutionalcreativitydemonstrated by the Workers' Party administration in Belo
Horizonte illuminates the government's commitment of making these participatory programs work - the upper echelon of the government work within their founding projects and created new institutional forms. Thus, participatory governance institutions are designed to draw people into formal policymaking processes so that they can promote their interests within the social justice frame. This helps governments and citizens better coordinate demand-making.

However, the blurring of the distinction between state and society entails a risk of bringing clientelism and co-optation into the new democratic institutions. Social movement and community leaders may find it increasingly difficult to maintain their political positions that are independent of the elected government. The election of community leaders to the participatory "seats" (conselhos, OP, confêrencias) positions them as representatives of civil society working inside the state, but they are also representative of state institutions as they work within civil society. Public officials gain access to information regarding the needs of the most vulnerable members of society. Government officials work closely with these leaders because there are obvious policy and electoral gains to be derived from this.

In sum, this section illustrates how the local state is being re-engineered in Belo Horizonte to incorporate citizens directly into policymaking venues. The process is taking place all over Brazil as mayors comply with federal mandates (i.e. councils in education, and health care) and federal incentives (i.e. the conference system). Access to the state is being demonopolized, thus allowing citizens to forge new ties and connections. The direct involvement of government officials and citizens through interlocking institutions 
is the final part of this analysis.

\section{Interlocking institutions}

The third pillar of state reform was the development of interlocking institutions, which link different agencies and link state officials to CSOs and citizens. One of Madison's key ideas in the Federalist Papers is that drawing engaged political actors into interlocking institution process will force their "ambition to counteract ambition," which would induce political actors to monitor others' activities as well as temper their own demands because political actors are forced to negotiate with their rivals. Thus, interlocking institutions have a democratizing effect as they encourage transparency, promote elite negotiation and induce politically active citizens to work within formal institutions Modern states seek to develop strategies to overcome institutional arrangement that forces government departments out of their policy silos. Agencies need to work with other agencies as a means to develop more comprehensive and holistic policy agendas. There are three basic types of interlocking institutions: Vertical, which link policy actors within same policy arenas and state agencies; Horizontal, which link policy actors across different policy arenas and state agencies; and Societal, which link public officials to CSO leaders and citizens

The Societal interlocking institutions are comprised of the offices and seats allocated to citizens in participatory governance (see section above); these offices CSO leaders directly to government officials to the corresponding policy arena. Citizens, and not professional politicians, are given some legal rights to make policy decisions, which creates an interdependence among citizens and government officials.
Their interests are brought closer together because their mutual approval is necessary to produce policy outcomes. The delegation of authority represents a turning point because it provides citizens and CSO leaders with direct decision-making authority within formal state institutions.

Figure 1 - Societal Interlocking institutions

Neighborhood level

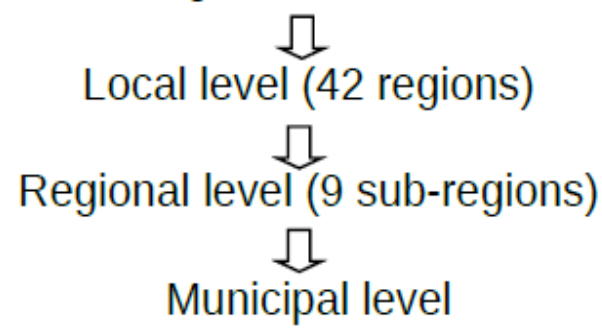

In addition, societal interlocking institutions link municipal-level public policy management councils to each other. In some councils, seats are allocated to members of other councils, which promotes the spread of information. This allows for information sharing between relevant councils as well as learning from the individual council member. Similarly, councils in the fields of health care and social services were also vertically linked, from the local level to the regional to municipal. This vertical linkage allows information to more quickly upwards and downwards. When government officials propose a new idea at the municipal level, citizens take the information from the municipal meeting to the regional and then to the local meeting. Conversely, when there is a problem at the local level, the information can quickly find its way into the municipal council and then into the offices of key policy experts. For example, 
beginning in 2010 , the municipal health care secretary in Belo Horizonte held a weekly meeting with the four government officials who were current members of the Health Care Council. The purpose was for the secretary to gather information on key CSO leaders' demands and opinions as expressed in the formal council meeting as well as in informal exchanges.

The constant contact thus allows government officials to be aware of the intensity and evolution of CSO leaders' demands. Government officials provide organizational support to help CSOs and their followers attend different participatory governance events. This constant contact is where the blurring of state and civil society occurs.

The vertical interlocking institutions link government officials, political appointees, and civil servants within each department to others within their agencies. The Belo Horizonte government created specific intragovernmental conselhos to alert first-tier decision-makers of the problems identified by their subordinates. There was simultaneously a concentration of authority in an intragovernment conselho as well as improved communication between key decision-makers and their agency's employees. Importantly, the vertical interlocking institutions run parallel to the vertical integration of the CSO leaders' involvement in the public policy management councils. When there is a problem at the local level, such as a school or health care clinic, there are two parallel information-sharing track-one is through intra-government channels and the other is through the council system. These can be mutually reinforcing as both state and society channels are used to send signals to key decision-makers.

The horizontal connections include internal administrative bodies that induce different agencies to work with other to create comprehensive policy solutions to seemingly intractable policy problems. Different agencies thus work with each other to produce comprehensive solutions to difficult social problems. To illustrate this point, we turn to the housing sector. Building housing units in distant isolated areas often occurred in Brazil but was a poorpolicy decisions because the residents relocated to them lacked access to school, health clinics. When the Belo Horizonte government began to plan new housing units, they required that different agencies, such as the housing, education, health and social services work together on the project (BEDE, 2005:163). There was a concerted effort to link the different agencies as a means to improve policy outcomes and to break up the bureaucratic fiefdoms that often characterize modern states.

Analytically, it is possible to draw lines between these three types of interlocking institutions. But in practice there is significant overlapping of the three types of interaction. The case of a housing program, Vila Viva, illustrates this point. In 2000, under Mayor Célio de Castro, the participatory budgeting program began requiring larger favelas to have urbanization plans prior to the implementation of major infrastructure projects. CSOs inside the favelas had to first organize themselves to secure the resources via $\mathrm{PB}$ to pay for the urbanization plan to be drawn up. The private-public municipal urbanization company, URBEL, designed the plans but they required the formal approval of the plan by community members as well as by appropriate municipal and state agencies. There was a concerted effort to involve multiple sectors 
in the process. After the urbanization plan was approved, CSOs, citizens and government officials then had to find the resources-At times, this was via PB or PB Housing, but at other times involved securing state or federal loans. The program Vila Viva was designed to work with the urbanization plans that allowed for new housing units to be built within an existing favelas. The cost was enormous, which meant that the municipality had to turn to BNDES and Caixa Econômica for funding. This example shows how ideas begun at the local level were then moved up and across different policy sectors. The state morphed, the state simplified favelas, but did so with metis, thus allowing for significant change in how state-society relations.

As with social justice and popular participation, there are potential drawbacks to the new system of interlocking institution. First, these institutions are housed within the executivebranch, whichextendsalongtradition of weak legislatures and strong executives in Brazil. These interlocking institutions help to improve coordination problems within the state by linking institutions, but these institutions has weak powers to check the authority of the executive. The logic of multiparty Presidentialism, used by Presidents Cardoso, Lula, and Dilma, is developing as a key negotiating pattern within participatory institutions. Individuals and groups seek to align themselves with the executive branch to secure benefits. Negotiation and dialogue are used by elected council members to pressure members of the executive branch to respond to basic demands.

Second, there is great variation across Belo Horizonte's different agencies regarding how they will interact with the participatory institutions. If we accept the notion the state is fragmented, with different interests, then the process of grafting the new interlocking institutions will take place differently across sectoral, spatial, political, and temporal lines. Thus, as other Brazilian municipalities and states as well as the federal government adopt the basic institutional design of participatory institutions, we would expect great variation in how the new system of interlocking institutions is put in place. Future political conflict at the municipal and state level will revolve around governments link participatory institutions to existing state institutions.

\section{Concluding Thoughts}

The institutional reengineering of the local state has altered how, when, and where government officials engage citizens and CSO leaders, which has shifts civil society organizing state-society relations, and party politics. The expansion of the "surface area of the state" now means that there are multiple venues for contact and interaction. Citizens and CSOs no longer have to rely on a limited number of government officials to place their claims on the state. There has been the demonopolization of control over state authority and resources, which increases the ability of citizens and CSOs to exit from non-productive relationship and "shop around" for new political alliances. Citizens unable to access these new state models are more likely to rely on clientelistic exchanges because of the inability to access the new institutional opportunities. This article focuses on innovations in Belo Horizonte, where there are important clues regarding how Brazil's high number of municipal states are being redesigned to accommodate constitutional and federal mandates. 
The policymaking process is now much broader, much more porous. The expanded surface area of the state induces the continual interaction of public officials and citizens. By linking elected officials, civil servants, political appointees, policy experts with different groups of citizens, the local state that is less likely to trample on the rights of ordinary citizens and will be more effective at securing the social rights formally guaranteed to citizens under the 1988 Constitution. The complex participatory governance architecture allows citizens the right to be involved in shaping their future, thus helping to build Sen's human capabilities (Sen 1999). The interlocking institutions induce potential competitors to work together to produce better policy outcomes.

Of course, and importantly, citizens, CSO leaders and government officials working within these new policy processes seek to exploit the political knowledge gained through these processes. Government officials use the new processes to assess the mobilizational capacity of CSOs, to gauge the intensity and evolution of demands, and to build electoral campaigns. CSO leaders use the new state institutions to draw the attention of potential government allies as a means to show the worthiness of their demands and their capacity to mobilize.

The construction of the new state does not necessarily mean that previous political practices such as clientelism or co-optation will disappear; these traditional political practices will find new places in the new political order. However, there is a key difference in so far as civil society leaders can now negotiate with a greater range of public officials, and thus increase their potential bargaining position.

Institutional change is currently occurring at incremental rates, but the change is likely to be far-reaching as political incentives for citizens and government officials are being altered. Citizens in Belo Horizonte experiences the first wave of cutting edge change, but we would expect that strengthening municipal states across Brazil to move in the same direction as Belo Horizonte because of the similarities of political incentives. There will obviously continue to be significant variation in how the new state is adopted and adapted across Brazil, but the three pillars of changesocial justice, popular participation, and interlocking institutions-are at the heart of reform efforts.

In sum, the new participatory governance architecture transforms both policy and political processes at the local level. The expansion of the surface area of the state alters the breadth and intensity of interactions among citizens and government officials. This has important democratizing effects because there is an increase in the number of voices heard in formal policymaking processes. The policymaking process benefits from linking local knowledge to expert and technical knowledge. The increasing complexity of the institutional structure may reduce some of the vitality of democratic life as CSO leaders and citizens now need to work within multiple institutional environments, but it helps to improve the quality of policy outputs and state activity. The increase number of signals between citizens and government officials expands outside of participatory institutions to affect the practices of representative democracy.

\section{Bibliographical References}

ABERS, R. Inventing Local Democracy: 
Grassroots Politics in Brazil. Boulder: Lynne Reinner Publishers. 2000.

ALVAREZ, S. Engendering Democracy in Brazil. Women's Movement in Transition Politics. Princeyon: Princeton University Press, 1990.

AVRITZER, L. Democracy and the Public Space in Latin America. Princeton: Princeton University Press, 2002.

AVRITZER, L. Participatory Institution in Democratic Brazil. Baltimore: John Hopkins University Press, 2009.

AZEVEDO, S.;FERNANDES, R. Orçamento Participativo: Construindo a Democracia. Rio de Janeiro: Renevan, 2005.

AZEVEDO, S.; NABUCO, A. Democracia Participativa: A Experiência de Belo Horizonte. Belo Horizonte: Editora Leitura, 2008.

BAIOCCHI, G. Militants and citizens: the politics of participation in Porto Alegre. Stanford: Stanford University Press, 2005.

BAIOCCHI, G; HELLER, P.; SILVA, M.K. Bootstrapping Democracy Transforming Local governance and civic society in Brazil. Stanford: Stanford University Press, 2011.

BEDÊ, M. Trajetória da formulação e implantação da política habitacional de Belo Horizonte na gestão da Frente BH Popular 1993 / 1996. Dissertação de Mestrado. Universidade Federal de Minas Gerais, 2005.
COLLIER, D.; COLLIER, R. Shaping the Political Arena: Critical Junctures, the Labor Movement, and Regime Dynamics in Latin America. Princeton: Princeton University Press, 1991.

DAGNINO, E. Os movimentos sociais e a emergência de uma nova noção de cidadania. In: Dagnino, E. (org.). Anos 90: política e sociedade no Brasil. São Paulo, Brasiliense, 1994, pp.103-15

FEDOZZI, L. Orçamento Participativo: Reflexões Sobre a Experiência de Porto Alegre. Porto Alegre: Tomo Editorial, 1998.

FEDOZZI, L. O Poder da Aldeia: Gênese e História do Orçamento Participativo de Porto Alegre. Porto Alegre: Tomo Editorial, 2000.

FUNG, A.; WRIGHT, E. Deepening Democracy: Innovations in Empowered Participatory Governance." Politics \& Society 29. (2001): 5-41.

FUNG, A.; WRIGHT, E. Deepening Democracy: Institutional Innovation in Empowered Participatory Governance. London: Verso Books, 2003.

HOLSTON, J. "Insurgent Citizenship: Disjunctions of Democracy and Modernity in Brazil." City \& Society, 21, no. 2 (2009): 245-267.

KECK, M. The Workers' Party and Democratization in Brazil. New Haven: Yale University Press, 1992.

KEY, V.O. Politics, Parties and Pressure Groups. New York: Thomas $Y$ 
ARTIGO: RE-ENGINEERING THE LOCAL STATE: PARTICIPATION, SOCIAL JUSTICE AND INTERLOCKING INSTITUTIONS

Cromwell Company, 1964.

\section{KOHLI, A. State-Directed Development:} Political Power and Industrialization in the Global Periphery. Cambridge: Cambridge University Press, 2004.

\section{LIPSKY, M. Street-level Bureaucracy:} Dilemmas of the Individual in Public Services. New York: Russell Sage Foundation, 1980.

MACHADO, A. Belo Horizonte "Democrática-Popular": Uma análise descritiva instituições de participação popular em Belo Horizonte. Dissertação de Mestrado. Universidade Federal de Minas Gerais, 2007.

MACHADO, M. Telma Gonçalves Menicucci; SOUSA, Zoraya Bernadete de. "A Experiência da Política de Segurança Alimentar e Nutricional de Belo Horizonte: Parcerias, Participação e Controle Social." Revista do Observatório do Milênio de Belo Horizonte, 2, no. 1 (2009): 83-99.

MIGDAL, J. State in Society: Studying How States and Societies Transform and Constitute One Another. New York: Cambridge University Press, 2001.

NAHAS, M; RIBEIRO, C; ESTEVES, O; MASCOVITCH, S; MARTINS, V. "O Mapa da Exclusão Social de Belo Horizonte." Caderno Ciência Sociais, 7, no. 10 (2000): 75-88.

OSTROM, E. Governing the Commons: The Evolution of Institutions for Collective Action. Cambridge: Cambridge University Press, 1990.
SCOTT, J. Seeing Like a State: How Certain Schemes to Improve the Human Condition Have Failed. New Haven: Yale University Press, 1998.

SEN, A. Development as Freedom. Oxford: Oxford University Press, 1999.

WAMPLER, Brian. Participatory Budgeting in Brazil: contestation, cooperation, and accountability. University Park: Pennsylvania State University Press, 2007.

YASHAR, D. Contesting Citizenship in Latin America: The Rise of Indigenous Movements and the Post Liberal Challenge. Cambridge: Cambridge University Press, 2005.

\section{Notes}

1. Regional Venues are councils in the areas of health care ( 9 venues, 183 citizens, 75 government officials, 92 government workers), social services (9 venues, 54 citizens, 9 government officials), conselho titular (9 venues, 45 elected (and paid) citizens), $\mathrm{BH}$ Transports,(10 venues, 50 citizens, 40 government officials (2 are from public bus company), 40 union officials) Diário oficial de Belo Horizonte: DECRETO № 13.920 DE 16 DE ABRIL DE 2010, Parks (15 venues, 45 citizens)

2. Local venues include an urbanization program Vila Viva (25 venues, 276 citizens, 10 government officials), local health posts (141 venues, 141 citizens, 141 government officials, and 141 union representatives), schools (186 schools, 1700 citizens, 1116 school officials), social services (54 schools, 108 citizens, 54 government officials), BH Cidadania (25 venues, 50 citizens, and 75 government officials, civil defense (48 teams, 400 citizens, and 10 government officials). Vila Viva data was provided by Ana Flávia 
Machado Martins, Chief-of-Staff of Urbel President on April 14, 2010. Personal communication. Education data was provided by Flávia Julião, Director of the School Stipend program for the municipality of Belo Horizonte on April 12, 2010. Civil Defense data was provided by Ana Flávia Machado Martins, Chief-of-Staff of Urbel President on April 14, 2010;. Education data was provided by Flávia Julião on April 19, 2010. Social Service data was provided by Sávio Araújo, Executive Secretary to the Municipal Social Service Council. Personal communication, April 16, 2010. $\mathrm{BH}$ Cidadania data was provided by Marcus Aníbal Rego on April 23, 2010. Document is entitled "ESTRUTURA DE GESTÃO DO PROGRAMA BH CIDADANIA" Prefeitura de Belo Horizonte.

3. Participation number for PB Regional is taken from the municipality's website, www.pbh.gov.br. See Chapter 3 for a fuller discussion of participation in PB.

4. The number of PB delegates fluctuates from year to year. Every two years, new members of the Comforça are elected to monitor the implementation process. Over the past several PB cycles, roughly 850 Comforça have been elected during the biannual electoral cycle. However, the rules of the Comforça state that the mandate of the members continues until all projects from that regional's project list are completed. Thus, in 2009, there were still Comforça members from the 1999 PB cycle in some regions due to slow implementation.

5. There was a minimum of 9,000 participants, but there are probably many more because we were only able to gather participation data on 9 of the 19 conferences. 